\title{
From the Perspective of Ecological Civilization: Moral Education in Colleges and Universities
}

\author{
Mei-Yan ZHU \\ Zhejiang University Ningbo Institute of Technology, Ningbo, China \\ Email: nbzhmy@126.com \\ Corresponding author: Mei-Yan ZHU
} Keywords: Ecological civilization, Moral education in colleges and universities, Ecological
mankind.

\begin{abstract}
The construction of ecological civilization is a pioneering idea advanced by the communist party of China while governing the country. In order to live in harmony with nature, protect the environment, build a beautiful China, and create a better life as well as achieve the abiding development of society, institutions of higher learning should incorporate the education of ecological civilization into the morality lessons provided for students, endeavor to cultivate them into "ecological mankind", explore the way to peacefully coexist with nature and vigorously press ahead with ecological practices.
\end{abstract}

\section{Introduction}

Along with the progress of society and transition of times, moral education in higher institutions has undergone incessant transformations, which shifts its focus from interpersonal relationships to relations between man and nature. As colleges and universities continue to expand the content of moral teaching, the education on ecological civilization has become part and parcel of the subject. So, what does moral education from the perspective of ecological civilization aim for? In my view, it can be said that the most fundamental goal is to foster college students into "ecological mankind", deconstruct and then reconstruct the relationships between humanity and nature as well as make great efforts to push forward the ecological practice.

\section{To Cultivate Students into “Ecological Persons”}

\section{The Appearance of Ecological Man}

The bygone twentieth century had witnessed enormous material wealth brought by industrial civilization, which, at the same time, did great damage to the ecological environment, leading to ecological crisis such as the pollution of water, air, and soil, the extinction of some species and global warming. In order to cope with such a dilemma, human beings need a more advanced and new form of civilization. Ecological civilization is a rational choice made by people under such a circumstance. The Chinese scholar named Yu Keping believed that "ecological civilization manifests all the efforts and accomplishments made by human beings during the course of achieving the peaceful coexistence between man and nature through reforming nature for the benefit themselves. It stands for the progress of relations between man and nature.”(2005)

The construction of ecological civilization was first put forth by the17th National Congress of the CPC, which made it a new goal of building a moderately prosperous society in an all-round way. While, the 18th National Congress regarded the construction of ecological civilization as the first step of realizing the strategic conception of "beautiful China", laid great emphasis on the rudimentary role it played in the overall structure, which includes the construction of ecological civilization, economy, politics, culture and society. The transformation of civilization requires that people change themselves first, and ecological civilization calls for the cultivation of ecological mankind.

Ecological civilization, which entails sincerity, kindness and beauty, represents human beings' 
pursuit of ideals. In order to act in compliance with the principle inherent in ecological civilization, ecological persons are supposed to seek truth, benevolence and beauty. From my perspective, ecological mankind can recognize the law of nature, and is wise enough to proceed in accordance with the law of nature. Ecological mankind has good aesthetic taste and is endowed with the freedom to create a better life. The concept of ecological persons enriches and broadens the connotation of human beings. It embodies the objective demand of the construction of ecological civilization and a beautiful China, and meets the need of comprehensive and unfettered development of mankind as a whole. Moral education in schools of higher learning, whose fundamental goal is to care about the development of people and create a better life for them, should make great efforts to rear "ecological mankind”.

\section{The Definition of "Ecological Mankind"}

Ecological persons can recognize the law of nature, and are wise enough to act accordingly. Nature is an objective fact that no one can possibly deny. While people seek to take advantage of and transform nature in a reasonable manner, it should be built on the true insight into the mystery, essence, and law of nature. For example, questions like "what is nature?”, "how does nature work?", "what is the law of nature?" and so forth are often asked. With unrelenting exploration of the aforementioned issues, people can finally grasp the true essence of nature. Undoubtedly, this is just the process that human beings acquire the wisdom through constant quest and exploration of nature. German philosopher, Friedrich Von Engels, once stated that: "the reason why human beings could reign over the world is that they are stronger than other animals and are able to perceive and utilize the law of nature in a right way.” Ecological persons can have a scientific comprehension of nature, in particular the law of nature, and act correspondingly. In actuality, they can voluntarily abide by the law of nature and strive for the peaceful coexistence between man and nature.

Ecological persons show their morality by respecting lives and treat nature kindly. What's more, ecological mankind tends to deem that people are equal with nature, all the species on the planet have the right to survival, and their relationships with human beings are inextricably intertwined. Doctor Peng Liwei said that: "the introduction of the concept of ecological persons indicates that, for the first time, moral concern has come to involve the love of nature, expanding the focus of attention from only human to the entire planet.” Ecological mankind expands the love of oneself to the love of other people and animals, and shows the concern for the planet as a whole, thus becoming moral persons. Just as French bioethicist Albert Schweitzer remarked: "goodness consists in maintaining, assisting and enhancing life, and to destroy, to harm or to hinder life is evil. Such is the inevitable, universal and absolute principle of ethics.”

Ecological mankind should be possessed of aesthetic faculty, and have the free rein to create a better life. Great German thinker, Karl Heinrich Marx, once said: “Animals can build according to the standard and needs of their own species, while man knows how to carry out his production in line with the criteria of any species, and how to apply them appropriately. Therefore, people produce in conformity with the law of aesthetics." From what has been mentioned above, the law of beauty is the combination of both internal and external yardstick, namely the unification of purposefulness and regularity. Ecological persons, in accordance with the nature and law of things, attempt to tap into and reform nature properly in reality, so as to satisfy felicitous needs of human beings, and bring benefits to them. Only in this way can man live peacefully with nature. Such is an action of aesthetics that constitutes the objectification of essential power and conscious activity of mankind. According to Gao Ertai, a Chinese aesthete, he believed that: "Beauty is the symbol of liberty”.

\section{To Explore Ways to Live in Harmony with Nature}

\section{To Deconstruct the Binary Relation between Man and Nature}

How should man get along with nature? For a long period of time, there has been a dichotomy between man and nature with one being naturalism and the other being anthropocentrism. 
According to naturalism, man is create by nature, thus people should take nature as the center. And human beings are dependent on and inferior to nature, they ought to revere and conform to the law of nature. On the contrary, what anthropocentrism tends to believe is that man is independent from nature, the most intelligent of all things, and the master of nature, hence mankind should be the kernel of the planet and is supposed to dominate and subjugate nature. Moreover, nature is the passive object that will be conquered and transformed by human, and man has absolute control over nature. Based on the aforementioned two ideas, it seems that they contradict with each other, but actually both of the two theories try to expatiate on the antagonism between man and nature, sever the correlation and unity between them and fail to get a correct apprehension of their relationship. Therefore, neither of the two views is theoretically flawless.

Naturalism aggrandizes the position and role of nature, while disavows the subjectivity and initiative of people, and entertains contempt for human beings. Conversely, anthropocentrism overrates mankind's leading role and function, but turns a blind eye to the counteractive effect that nature has on people, which signifies the encroachment of man on nature. Theoretical errors can do a great disservice to practice. According to naturalism, man is insignificant and powerless, and mankind has to succumb to nature and be at the mercy of it, thus people should forgo the proper utilization and reformation of nature. However, based on anthropocentrism, man can conquer nature, and despoil and destroy nature at will. Whilst mankind declares war on nature, people are also faced with punishment and retaliation meted out by it. Like Friedrich Von Engels, a famous German philosopher, said: "we should not be immersed in the triumph over nature, because human beings have already been taken revenge on by nature for every victory they have.” The exacerbated relationship between man and nature has given rise to ecological crisis and posed a severe threat to the survival and lasting development of mankind as a whole.

As a result, neither of the theories mentioned above can benefit people in a real sense. To solve such an antithesis between man and nature, it's high time that people found a way to live harmoniously with nature.

\section{Reconstruct the Harmonious Relationship between Man and Nature}

The appearance of ecological mankind has offered a solution to the contradictory relation between man and nature as well as the reconstruction of harmonious relationship between them. According to ecological persons, man and nature compose an ecological system within certain space, and none of them is isolated from each other, but they are closely interrelated and interdependent, forming a community of shared destiny. Hence, moral education in colleges and universities from the perspective of ecological civilization should help students learn how to coexist with nature, respect and protect nature, so that man can achieve the development along with nature that is differentiated, mutually enhancing and harmonious.

Human beings eventually come to realize that they are neither the slave of nature nor the ruler of nature through painful lessons in the past. Instead, man is equal to nature. Doctor Liu Xiaoju pointed out that: "the relationship between man and nature should be equal without one being subordinate to or conquered by another. The history of mankind has never been about wars against nature nor conflicts among people. On the contrary, man can live in harmony with nature.”(2011) Both man and nature play an indispensable role in ecological system. They are tightly interconnected and mutually interactive and will thrive together. As long as man treat nature equally and kindly, coexist with nature, respect nature, and act in accordance with the law of nature, the problem of binary relation between man and nature can be solved, and finally man can accomplish the peaceful coexistence with nature.

From being awed by and conquering nature to reverence for nature, human beings have experienced a dialectical negative process, after which they locate a path to a peaceful coexistence and coordinated development with nature. It is the only way to the future that mankind can choose, which represents a redemption for humanity itself. To reconstruct the peaceful relationship between man and nature is to readjust human's behaviors on the one hand. On the other hand, it is also to pinpoint a new purpose for social evolvement and lay a solid foundation for the creation of a better 
life.

\section{To Take an Active Part in Ecological Practice}

The target of ecological practice is to create an enabling ecological environment and strive for a beautiful homeland and a better life for humanity. Ecological practice provides an opportunity for people to engage in ecological aesthetic experiences and participate in ecological construction, through which human beings can lead a better life. For one thing, moral education in institutions of higher learning should try its best to offer more channels for students to be close to nature, and appreciate and experience the beauty of ecological environment. For another, schools should let students partake in ecological constructions as much as possible and attempt to create a better life with their own efforts.

\section{Ecological Aesthetic Experience}

Man is created by nature, and has an intrinsic affinity with nature. "Ecological aesthetics believes that nature constitutes not only material basis for the survival of human beings, but serves as a spiritual sanctuary where people can have emotional connection, consolation and pleasure."(Peng Li-wei, 2009) Moral education in universities ought to envisage some activities concerning ecology such as holding a photographic exhibition of beautiful landscapes, taking pictures of natural sceneries, and encouraging students to pay a visit to forest parks, fields in the countryside, nature reserves and the like during holidays or in leisure time. In this way, students can come near to nature, appreciate nature, witness the holiness and lofty of nature via their ecological aesthetic experience, and pursue the unity between man and all livings on the earth, thus acquiring inner tranquility and freedom.

While being exposed to nature, people will involuntarily open their minds, and endeavor to have a genuine communication with nature with all their senses, observing all creatures in nature, beholding the sunrise and sunset, listening to the birds and sniffing the flowers, savoring the beautiful landscape and reveling in the beauty of nature. According to Hu Dong-fang, he wrote in his paper that : "the beauty of nature is diversified, such as the beauty of coordination through perfect color arrangement, symmetrical beauty of structure and proportion, harmonious beauty of combined elements, unified beauty coupled with different performances and so forth.”

Through ecological aesthetic experience, people can, on the one hand, feel pleasant both physically and mentally. On the other hand, they also show their love for nature and are concerned with all the living things on this planet. Therefore, man has gradually learned to care about not only themselves but all creatures in nature, and begun to respect, protect and revere nature. More importantly, individuals will try to integrate with all the other living things in nature, and become a loyal protector of nature and make all lives be in an immanently unrestrained state, hence achieving the unity of man and nature and truly crystallize the peaceful coexistence between the two.

\section{Be Engaged in Ecological Construction}

Ecological aesthetic experience purports to motivate students to love and pursue ecological beauty, which is the premise for building a more beautiful homeland for humanity as a whole. However, to lead mankind to a better life requires that moral education provided by schools of higher learning should teach students to apply the environmental philosophy to their daily life through various ways and take practical actions as well as proactively take part in the ecological construction. Specifically, in practice, great efforts must be made to constantly improve students' awareness of environmental protection, so that they can form a good ecological habit, have a healthier manner of consumption and adopt an energy-saving and low-carbon lifestyle.

Furthermore, student organizations pertinent to environmental protection should be established on the campus, and they can cultivate students into a publicist and advocator of environmental protection. Schools can also mobilize students to publicize the knowledge and policies relevant to environmental protection in places like tourist sites, communities, streets and so forth, contributing to the formation of a favorable atmosphere of ecological construction and environmental protection 
in society. In addition, in everyday life, students are asked to act in line with the philosophy of environmental protection such as diminishing daily rubbish, never polluting the environment, saving water and electricity, valuing and making good use of resources, refraining from wasting, buying and utilizing green products, and recycling instead of throwing away after items being used for only once. What's more, it's suggested that people change their transportation, and it would be more preferable for them to walk, ride a bike, take such public transport as buses and subways as much as possible, and avoid frequently driving cars. Besides, students should be encouraged to invent various environmental-friendly products such as sewage processor, air purifier, and other energy-saving and emission- reducing goods. In this way, people can conserve and make efficient use of resources, decrease pollution, protect environment and thus create a better life for themselves.

Schools are supposed to initiate various activities of environmental protection on a regular basis, for instance, motivating students to enter into public activities of environmental protection, conduct surveys on ecological environment, visit nature reserve zones, observe ecological laboratory and sewage disposal station, so that students may have a clear understanding of current environmental situation, enhance their awareness of environmental protection, master certain knowledge and skill with regards to environmental protection, and improve their research and problem-solving capabilities in this respect. Schools can also disseminate and popularize ecological knowledge among students via social media like publications, campus broadcast, and internet and so on, through which students can be cognizant of the gravity of environmental issues as well as exigency and magnitude of protecting the environment. Moreover, great efforts should be made to mobilize students to take real actions as advocators of environmental protection. Besides, on special holidays like Earth Day, World Environment Day, World Water Day, Arbor day and others, universities and colleges can appeal to students to take an active part in protecting the earth, economizing on water and electricity and planting more trees, thus improving and ameliorating the environment in a practical sense. By preaching country's policies, universities can propel students to consciously oversee our circumstances, bravely impeach and disclose anyone who attempt to jeopardize the environment and undertake the obligation and accountability of environmental protection.

People should consume in a more civilized and healthier manner. Impacted by extremism, materialism, hedonism, and consumerism, human beings are disposed to consume irrationally and unhealthily, and hence may have many improper consumption habits such as excessive consumption, extravagant consumption, premature consumption, one-off consumption, blind consumption, vicious consumption and the like. Individuals who consume in these ways are clearly oblivious to the handling capacity of natural resources and environment, and only want to suffice their avarice and desire. They disregard the needs of survival of their posterity, and indulge in the immediate pleasure, which manifests the selfishness, narrow-mindedness, and short-sightedness of humanity. Therefore, people must change the way they consume. Measures should be taken to advocate some healthy ways of consumption like moderate consumption, green consumption, reasonable consumption, sustainable consumption and so forth, striving to pose no harm, waste and pollution to the environment. Altering irrational and unhealthy ways of consumption shows mankind's love and concern for nature as well as the future and fate of itself.

Be committed to an energy-saving and low-carbon lifestyle. It is universally acknowledged that industrial civilization evolves at the cost of depletion of huge amount of energy and resources, which has severely affected the sustainable development of humanity and triggered environmental crisis such as global greenhouse effect. In 2009, at the UN Climate Change Conference, such ideas as "low-carbon economy", "low-carbon lifestyle" and others were put forward, so as to lessen the pressure on environment. As a consequence, we ought to have an energy-saving and low-carbon lifestyle characterizing low energy consumption and low spending, which is very wholesome, natural and safe. In our daily life, it is advisable for individuals to be frugal on such things as water, electricity, coal, gas, oil and so on, recycle more and utilize environmental-friendly products instead of using such household items like disposable chopsticks and cups, and napkins. What's more, green travel and low-carbon travel are highly recommended. 
In the final analysis, as long as everyone can proceed from oneself, start with trivialities, and participate in ecological construction, it won't be long before human beings create a homeland boasting beautiful landscape and agreeable climate, achieve the coordinated and unified development of man and nature, and eventually lead a better life.

\section{References}

[1]Yu Ke-ping.Scientific Outlook on Development and ecological civilization.Marxism and reality,2005(4): 4-5.

[2]Friedrich Engels.Dialectics of Nature.Bei Jing:People's Publishing House,1971:518.

[3]Peng li-wei.On Ecological Personality_—The Objective Appeal of Personality of Ecological Civilization.Educational Research,2012(9): 21-26.

[4]Albert Schweitzer.Reverence for Life. Shanghai academy of social sciences press,1995:127.

[5]Karl Marx.Economic and Philosophic Manuscripts of 1844.Bei Jing:People's Publishing House,1985:53-54.

[6]Marx Engels Selected Works(Volume 4).Bei Jing:People's Publishing House,1995:383.

[7]Liu Xiao-ju.On Ecological Civilization Construction from Historical Object Perspective.Journal of Hangzhou Dianzi University(Social Science),2011(1): 44-47.

[8]Peng li-wei. On Ecological Personality.Doctor Thesis of Hunan Normal University (2009).

[9]Hu Dong-fang.On the Moral Education of Value of Environmental Education.Education Review,1997(5): 19-21. 